\begin{tabular}{c|c|c}
\hline \hline $\begin{array}{c}\text { Vol. 35(4):273-280 } \\
\text { http://dx.doi.org/10.4217/OPR.2013.35.4.273 }\end{array}$ & Ocean and Polar Research & December 2013 \\
\hline \hline
\end{tabular}

\title{
Article
}

\author{
넓미역의 영양성분 및 항산화 활성 \\ 조명래* · 윤성진 · 김윤배 \\ 한국해양과학기술원 동해연구소 \\ (767-813) 경북 울진군 죽변면 해양과학길 48
}

\section{The Nutritional Composition and Antioxidant Activity from Undariopsis peterseniana}

\author{
MyoungLae Cho*, Sung Jin Yoon, and Yun-Bae Kim \\ East Sea Research Institute, KIOST \\ Uljin 767-813, Korea
}

\begin{abstract}
The proximate composition, free amino acid composition and mineral contents from Undariopsis peterseniana were determined, and the antioxidant activities of ethanol (EtOH) and hot water extracts of $U$. peterseniana were investigated using DPPH (1,1-diphenyl-1-picrylhydrazyl), ABTS (2,2'azino-bis(3-ethylbenzothiazoline-6-sulphonic acid)) radical scavenging effects and reducing power. The contents of moisture, ash, protein, lipid and carbohydrate were $12.5 \%, 23.1 \%, 9.7 \%, 0.2 \%$ and $54.5 \%$, respectively, and alginic acid content was $12.3 \%$. The major free amino acid contents were alanine, phenylalanine, aminoethanol, valine, glutamic acid and phosphoserine. Ca (1589.1 mg) was the largest mineral followed by $\mathrm{Na}(344.6 \mathrm{mg}), \mathrm{Mg}(74.3 \mathrm{mg}), \mathrm{Zn}(10.2 \mathrm{mg})$ and Fe $(1.5 \mathrm{mg})$. The total phenolic contents of EtOH and hot water extracts were exhibited at 15.7 and $4.3 \mathrm{mg}$ GAE/g sample, respectively. The antioxidant activity of EtOH extract exhibited strong ABTS and DPPH radical scavenging activities with reducing power, and hot water extract also demonstrated strong ABTS radical scavenging effects. Therefore, the results of this study suggest that $U$. peterseniana contained an abundance of naturally occurring nutrients (free amino acids and minerals), and the strong antioxidant activities of EtOH and hot water extracts from $U$. peterseniana could be good sources of natural antioxidants for healthcare products.
\end{abstract}

Key words : Undariopsis peterseniana, free amino acid, ABTS, DPPH, reducing power

\section{1. 서 론}

활성산소종(Reactive oxygen species, ROS)은 체내에서 산화작용을 일으키며 생체내의 세포막, 단백질, DNA 및 효소 등을 손상시켜 각종 질병의 원인이 되는 것으로 알 려져 있다(Feskanich et al. 1992; Regnstrom et al. 1992). 이에 일부 식품, 화장품 및 의학품 산업에서는 $\operatorname{ROS}$ 를 효 과적으로 제거하기 위한 방법으로 저비용의 butylated

*Corresponding author. E-mail : mlcho@kiost.ac
hydroxyanisole(BHA), butylated hydroxytoluene(BHT), propyl gallate(PG)와 같은 합성 항산화제를 사용하고 있 다. 그러나 많은 연구들에서 보고된 바와 같이 합성 항산 화제는 세포내 독성을 나타내거나 암을 유발하는 등의 부 작용이 우려되기 때문에 이를 대체할 수 있는 물질 개발 연구가 시급한 상황이다(Ito et al. 1986; Safer and alNughamish 1999). 따라서, 합성 항산화제보다 더 효능이 좋으며, 안전한 물질을 찾기 위하여 천연물을 이용한 항산 화 연구는 꾸준히 수행되어 왔다. 그 결과, 육상 생물에서 는 quercetin, phenolic acid, flavonoids, 해양생물에서는 
pheophorbide a, phlorotannins, chlorophyll analogs 등과 같은 항산화 물질이 분리되었다(Rice-Evans et al. 1996; Yan et al. 1996; Azuma et al. 1999; Nakayama et al. 1999; Cho et al. 2011a).

미역(Undaria pinnatifida)은 다시마목 미역과의 갈조류 로 우리나라의 전 연안에 서식하며 연해주, 중국 및 일본 등 극동 지방에 흔하게 자생하는 해조류이고, 미네랄 $(\mathrm{Na}$,

$\mathrm{K}, \mathrm{Ca}, \mathrm{Mg}, \mathrm{P}, \mathrm{S}$ 등) 및 필수 아미노산(threonin, valine, methionine, lysine 등)이 풍부하게 함유되어 있는 것으로 알려져 있다(Choi et al. 2008). 또한, 미역에 함유되어 있 는 저분자 물질인 fucoxanthin은 항암, 항염증, 항산화 및 항비만 등에 효과가 있다고 보고 되었으며, 고분자 다당류 인 알긴산은 중금속 배출, 콜레스테롤 저하, 비만 및 변비 방지 효과, 함황 다당류인 퓨코이단은 항암, 항산화, 항혈 액응고, 항노화 등의 다양한 생리활성이 있다고 보고되었 다(Hosokawa et al. 1999; Maeda et al. 2005; Khan et al. 2007; Sachindra et al. 2007; Choi et al. 2008; Cho et al. 2011b).

넓미역(Undariopsis peterseniana)은 미역과의 해조류로 우리나라에는 주로 제주도 종달리, 우도, 가파도 및 청산 도와 같이, 쓰시마 난류의 영향을 직접적으로 받는 지역의 수심 $15 \mathrm{~m}$ 조하대 부근에 서식하는 것으로 알려져 있다 (Lee and Koh 1991; Lee et al. 1991; Kang 1996; Lee 1998; Hwang et al. 2010a). 지금까지 수행된 넓미역에 관 한 연구는 대량생산을 위한 유리배우체의 재생 및 성숙 유도, 보호대상 해조류로서 생장 및 성숙 과정을 관찰한 생태학적 특성 연구 등 주로 넓미역의 증양식 측면에서의 연구가 수행되었을 뿐(Hwang et al. 2010b; Hwang et al. 2011), 기능성 소재로써 넓미역의 이용 가치에 관한 체계 적인 연구는 거의 수행되지 않았다. 따라서, 본 연구는 국 내 자생 넓미역을 식품, 화장품 및 의약품 분야의 기능성 소재로 이용하고자 하였으며, 이를 위해 넓미역의 영양 성 분 분석을 수행하였고, 에탄올 $(\mathrm{EtOH})$ 과 열수로 추출한 추 출물의 폴리페놀 함량 및 항산화 활성을 연구하였다.

\section{2. 재료 및 방법}

\section{재료}

본 연구에 사용된 넓미역(U. peterseniana)은 2013년도 7월 에 울릉군 서면 태하리에서 채집하였다. 채집된 넓미역은 증 류수로 헹구어 낸 후, $40^{\circ} \mathrm{C}$ 에서 건조, 마쇄 후, $-20^{\circ} \mathrm{C}$ 에서 보 관하였다. ABTS (2,2'-azino-bis(3-ethylbenzothiazoline-6sulphonic acid)), DPPH (1,1-diphenyl-1-picrylhydrazyl), TCA (trichloroacetic acid), potassium ferricyanide, potassium persulfate, ferric chloride, Folin-Ciocalteu reagent, gallic acid, ascorbic acid (V.C), BHA (butylated hydroxyanisole)
등의 시약은 Sigma-Aldrich사(St. Louis, MO, USA)에서 구 입하여 사용하였다.

\section{일반성분 분석}

넓미역의 수분, 회분, 조단백질, 조지방, 탄수화물 함량 은 Association of Official Agricultural Chemists (1995)의 방법에 따라 분석하였다. 수분은 상압가열건조법을 이용 하였으며, 회분은 회화로(F6010, Thermolyne, USA)에 옮 겨 $600^{\circ} \mathrm{C}$ 에서 12 시간 동안 가열하여 얻은 회화의 양을 측 정하였다. 조단백질은 킬달법을 적용한 분석기기인 auto kjeldahl system(Buchi B-324/435/412; Buchi, Flawil, Switzerland)을 이용하였으며, 조지방 분석은 에테르 추출 법을 이용하여 auto soxhlet system(SER 148, VELP Scientifica, Milano, Italy)으로 분석하였다. 탄수화물 함량 은 넓미역 시료 $100 \mathrm{~g}$ 중에서 수분, 회분, 조단백질 및 조 지방을 합한 값을 100 에서 뺀 값으로 하였다.

\section{유리아미노산 함량 분석}

넓미역의 아미노산 함량은 AOAC 방법(1995)에 따라 아미노산 분석기를 이용하여 분석 하였다. 넓미역 시료 $2.5 \mathrm{~g}$ 에 $70 \% \mathrm{EtOH} 20 \mathrm{~mL}$ 을 혼합하여 상온에서 6시간 동 안 교반 후, 증류수 $80 \mathrm{~mL}$ 을 첨가하여 시료를 희석하였 다. 희석된 시료를 $0.2 \mu \mathrm{m}$ filter(Whatman International, Maidstone, UK)를 이용하여 여과 후, 적량을 아미노산자 동분석기(L-8900, Hitachi, Japan)로 분석하였다.

\section{미네랄 함량 분석}

넓미역의 미네랄 함량 분석은 AOAC (1984) 방법에 따 라 분석하였다. 넓미역 시료 $10 \mathrm{~g}$ 을 회화용기에 취하여 예 비 탄화시킨 후 $600^{\circ} \mathrm{C}$ 에서 8 시간 동안 회화하였다. 회분 $5 \mathrm{~g}$ 과 $0.1 \mathrm{~N} \mathrm{HCl} 50 \mathrm{~mL}$ 을 혼합하여 상온에서 30 분간 교반 하고, $0.2 \mu \mathrm{m}$ filter(Whatman International, Maidstone, $\mathrm{UK})$ 를 이용하여 여과 후, 적량을 원자흡수분광광도계 (ALALYST100, Perkin Elmer, USA)를 사용하여 분석하 였다.

\section{알긴산 함량 측정}

넒미역에 함유된 알긴산 함량은 You et al. (1997)의 방 법을 응용하였다. 넓미역 시료 $10 \mathrm{~g}$ 에 $0.1 \%$ 탄산나트륨 $\left(\mathrm{Na}_{2} \mathrm{CO}_{3}\right) 500 \mathrm{~mL}$ 를 첨가하여 $60^{\circ} \mathrm{C}$ 항온수조에서 2시간 동안 가열한 다음, $500 \mathrm{~mL}$ 의 증류수를 첨가하였다. 혼합 물을 $8,000 \mathrm{rpm}$ 에서 10 분간 원심 분리하여 얻은 상등액 에 $99 \% \mathrm{EtOH} 1000 \mathrm{~mL}$ 를 첨가하여 침전시킨 후, $8,000 \mathrm{rpm}$ 으로 원심 분리하여 침전물을 회수하였다. 회수 된 침전물을 증류수로 용해한 다음 $99 \% \mathrm{EtOH}$ 를 첨가하 는 방식으로 2 회 더 알긴산을 정제한 후, 동결건조하여 
알긴산을 획득하였다.

\section{넓미역 EtOH 및 열수 추출물 제조}

넓미역의 $\mathrm{EtOH}$ 추출물은 넓미역 $10 \mathrm{~g}$ 에 $99 \% \mathrm{EtOH}$ $500 \mathrm{~mL}$ 를 첨가하여 상온에서 5시간 동안 교반추출을 이 용하여 3회 반복 추출하였다. $99 \% \mathrm{EtOH}$ 에서 추출한 시 료는 $40^{\circ} \mathrm{C}$ 에서 감압농축 하였으며, $30^{\circ} \mathrm{C}$ 진공오븐에서 건 조하였다.

넓미역의 열수 추출물은 넓미역 $10 \mathrm{~g}$ 에 $500 \mathrm{~mL}$ 의 증류 수를 첨가하여 $60^{\circ} \mathrm{C}$ 에서 2시간 동안 교반추출을 이용하 여 2회 반복 추출하였다. 증류수로 추출한 시료는 $50^{\circ} \mathrm{C}$ 에 서 감압농축 하였으며, 동결건조기를 이용하여 열수 추출 물을 획득하였다.

\section{DPPH 라디칼 소거능}

넓미역 $\mathrm{EtOH}$ 추출물 및 열수 추출물의 $\mathrm{DPPH}$ 라디칼 에 대한 소거능을 확인하기 위하여 Brand-Williams et al. (1995)의 방법을 응용하였다. $0.1 \mathrm{mM} \mathrm{DPPH} 100 \mu \mathrm{L}$ 와 넓 미역 추출물 $100 \mu \mathrm{L}$ 를 96 well-plate에 분주한 다음 상온 에서 30 분 동안 반응시키고, microplate reader(EL-800, BioTek Instruments, Winooski, VT, USA)의 $515 \mathrm{~nm}$ 에서 흡광도를 측정하였다. DPPH 라디칼 소거능은 아래의 계 산식을 사용하였다.

$\mathrm{DPPH}$ 라디칼 소거능 $(\%)=[(\mathrm{Ac}-\mathrm{As}) / \mathrm{Ac}] \times 100$

$\mathrm{Ac}$ : 대조군 흡광도, As: 시료군 흡광도

대조군은 시료 대신 에탄올을 첨가 하였으며, 비교를 위해 시중에서 사용되는 항산화제인 V.C와 BHA $(100 \mu \mathrm{g} /$ $\mathrm{mL}$ )를 사용하였다.

\section{ABTS 라디칼 소거능}

넓미역 $\mathrm{EtOH}$ 및 열수 추출물의 $\mathrm{ABTS}$ 라디칼 소거능 은 Re et al. (1999)의 방법을 응용하였다. $7 \mathrm{mM}$ 의 ABTS 와 $2.45 \mathrm{mM}$ 의 potassium persulfate를 첨가하여 암소에서 16 시간 방치한 후, $734 \mathrm{~nm}$ 에서 흡광도가 0.7-0.8이 되도 록 증류수로 희석하였다. 희석된 $\mathrm{ABTS} 1.5 \mathrm{~mL}$ 와 넓미역 추출물 시료 $0.5 \mathrm{~mL}$ 를 혼합하고, 상온에서 60 분간 반응시 킨 후, $734 \mathrm{~nm}$ 에서 흡광도를 측정하였다. ABTS 라디칼 소거능은 아래의 계산식을 사용하였다.

$\mathrm{ABTS}$ 라디칼 소거능 $(\%)=[(\mathrm{Ac}-\mathrm{As}) / \mathrm{Ac}] \times 100$

$\mathrm{Ac:}$ 대조군 흡광도, As: 시료군 흡광도

대조군은 시료 대신 에탄올을 첨가 하였으며, 비교를 위해 시중에서 사용되는 항산화제인 V.C와 $\mathrm{BHA}(100 \mu \mathrm{g} /$ $\mathrm{mL}$ )를 사용하였다.

\section{환원력 측정(Reducing power)}

넓미역 EtOH 및 열수 추출물의 reducing power는 Oyaizu (1986)의 방법을 응용하였다. 넓미역 추출물 $0.5 \mathrm{~mL}$ 와 sodium phosphate $\operatorname{buffer}(0.2 \mathrm{M}, \mathrm{pH}$ 6.6) $0.5 \mathrm{~mL}$ 및 $1 \%$ potassium ferricyanide $0.5 \mathrm{~mL}$ 를 첨가하여 $50{ }^{\circ} \mathrm{C}$ 항온수조에서 20 분 동안 반응시켰다. 반응 후, $10 \%$ $\mathrm{TCA}$ 용액을 $0.5 \mathrm{~mL}$ 첨가하고, $12,000 \mathrm{rpm}$ 에서 10 분간 원 심분리 하였다. 원심분리된 상등액 $1 \mathrm{~mL}$ 에 증류수 $1 \mathrm{~mL}$ 를 첨가하고, $0.1 \%$ ferric chloride $200 \mu \mathrm{L}$ 첨가하여 상온 에서 10 분간 반응 후 $700 \mathrm{~nm}$ 에서 흡광도를 측정하였다. 넓미역 추출물의 환원력을 비교하기 위하여 시중에서 사 용되는 항산화제인 V.C와 BHA $(10 \mu \mathrm{g} / \mathrm{mL})$ 를 사용하였다.

\section{총폴리페놀 함량 측정}

넓미역 $\mathrm{EtOH}$ 및 열수 추출물의 총폴리페놀 함량은 Folin-Ciocalteu 방법을 이용하였으며, Kahkonen et al. (1999)의 방법을 응용하였다. 넓미역 추출물에 함유되어 있는 총폴리페놀 함량은 $0.1 \mathrm{mg} / \mathrm{mL}$ 농도의 시료 $100 \mu \mathrm{L}$ 를 $400 \mu \mathrm{L}$ 증류수와 혼합하였다. 혼합된 시료와 $250 \mu \mathrm{L}$ 의 Folin-Ciocalteu reagent $(1.0 \mathrm{~N}), 1.25 \mathrm{~mL}$ 의 $12.5 \%$ sodium carbonate를 첨가하고, 상온에서 40분간 반응시킨 후 $750 \mathrm{~nm}$ 에서 흡광도를 측정하였다. 대조군은 시료 대신 에탄올을 첨가 하였으며, 표준물질로 Gallic acid를 이용 하여 표준물질의 표준곡선으로부터 총 폴리페놀 함량 $(\mathrm{mg}$ $\mathrm{GAE} / \mathrm{g}$ sample)을 계산하였다.

\section{통계분석}

이 연구에서 실험값은 SPSS 16.0 analysis software package의 paired $t$-test로 검정하여 통계 값을 구했으며, 모든 실험은 3 반복으로 측정하여 측정치를 평균값 \pm 표준 편차(Mean \pm standard deviation)로 나타내었다.

\section{3. 결과 및 고찰}

\section{넒미역의 일반성분 분석 및 알긴산 함량 측정}

넓미역의 일반성분과 알긴산 함량은 Table 1에 나타내 었다. 넓미역 $100 \mathrm{~g}$ (dry weight basis)중에는 수분 $12.5 \%$, 조회분 $23.1 \%$, 조단백질 $9.7 \%$, 조지방 $0.2 \%$, 탄수화물 $54.5 \%$ 가 함유되어 있었다. 이러한 결과는 Choi et al. (2008)이 보고한 기장, 진도 및 완도산 미역의 일반성분 (수분: 9.1-9.2\%, 조회분: 29.4-33.7\%, 조단백질: $11.7-$ $16.6 \%$, 조지방: $0.4-1.5 \%$, 탄수화물: $43.6-47.3 \%$ )과 유사 하게 나타났으며, Park et al. (2012)이 보고한 구멍쇠미역 의 일반성분(수분: $4.2 \%$, 조회분: $33.1 \%$, 조단백질: $15.0 \%$, 조지방: $2.3 \%$, 탄수화물: $45.6 \%$ )과도 유사한 결과 를 보였다. 따라서 넓미역의 일반성분은 완도, 진도, 기장 
Table 1. Proximate composition of $U$. peterseniana

\begin{tabular}{ccccccc}
\hline & Moisture & Ash & Protein & Lipid & Carbohydrate & Alginic acid \\
\hline Contents (\%) & $12.5 \pm 0.1$ & $23.1 \pm 0.3$ & $9.7 \pm 0.4$ & $0.2 \pm 0.1$ & $54.5 \pm 0.6$ & $12.3 \pm 0.5$ \\
\hline
\end{tabular}

산 미역 및 구멍쇠미역과 크게 차이를 보이지 않았다. 한 편, 넓미역에 함유되어 있는 알긴산 함량은 $12.3 \%$ 로 완 도, 진도, 기장산 미역에 함유되어 있는 알긴산 함량(21.0$27.8 \%$ ) 보다 낮게 나타났다(Choi et al. 2008). 이상의 연 구 결과에서 보듯이 넓미역의 일반성분은 완도, 진도, 기 장산 미역과 크게 차이를 보이지 않았으나, 알긴산 함량은 낮게 나타났다. 따라서, 넓미역에 함유되어 있는 기능성 다당류인 알긴산은 미역의 종(species) 에 따라 다르게 함 유되어 있는 것으로 보여진다.

\section{유리 아미노산 함량 분석}

넓미역에 함유되어 있는 구성 유리 아미노산은 Table 2 에 나타난 바와 같이, 총 21종류로 분석되었다. 넓미역의 아미노산 함량은 alanine이 가장 높았으며, phenylalanine, aminoethanol, valine, glutamic acid, phosphoserine 순으 로 나타났다. 한편, 기장산 미역에서는 proline, hydroxyproline 함량이 높게 나타났고, 구멍쇠미역에서는 glutamic

Table 2. Free amino acid compositions of $U$. peterseniana

\begin{tabular}{lc}
\hline Amino acids & $\begin{array}{c}\text { Contents } \\
\text { (mg/100g of dry weight) }\end{array}$ \\
\hline Phosphoserine & $32.6 \pm 1.4$ \\
Taurine & $17.4 \pm 1.3$ \\
aspartic acid & $1.5 \pm 0.1$ \\
Threonine & $7.3 \pm 0.4$ \\
Serine & $4.2 \pm 0.1$ \\
glutamic acid & $34.1 \pm 0.3$ \\
Glycine & $15.5 \pm 0.1$ \\
Alanine & $413.8 \pm 1.3$ \\
a-aminobutyric acid & $0.8 \pm 1.1$ \\
Valine & $37.2 \pm 1.5$ \\
Methionine & $11.9 \pm 0.1$ \\
Cystathionine & $6.6 \pm 0.8$ \\
Isoleucine & $4.4 \pm 0.4$ \\
Leucine & $11.7 \pm 1.6$ \\
Tyrosine & $19.7 \pm 1.5$ \\
Phenylalnine & $63.8 \pm 1.7$ \\
Aminoethanol & $39.8 \pm 1.4$ \\
Ammonia & $29.7 \pm 0.4$ \\
Ornithine & $1.4 \pm 0.3$ \\
Lysine & $7.4 \pm 0.1$ \\
Arginine & $9.0 \pm 0.3$ \\
\hline
\end{tabular}

acid, asparagines, alanine 함량이 높게 나타났다(Choi et al. 2008; Park et al. 2012). 넓미역에는 체내에서 합성되 지 않으며 반드시 음식으로 섭취해야 하는 필수 아미노산 인 phenylalanine, valine의 함량이 각각 $63.8,37.2 \mathrm{mg}$ (100 g dry weight basis)으로 비교적 높은 함유량을 보였 으며, 맛을 내는데 중요한 glutamic acid 역시 $34 \mathrm{mg}$ 으로 다른 아미노산 함량과 비교 하였을 때, 높은 함유량을 보 였다. 넓미역과 기장, 진도, 완도산 미역의 필수 아미노산 을 비교하면, 넓미역에 함유되어 있는 valine, methionine, leucine, phenylalanine은 기장, 진도, 완도산 미역보다 높게 나타났으며, threonine, isoleucine, lysine 등은 유사하게 나 타났다. 필수 아미노산은 식품 단백질의 영양적 가치 평가 의 기준으로서 매우 중요하다. 따라서, 넓미역은 다른 일반 미역보다 더 높은 영양적 가치를 가질 것으로 기대된다.

\section{미네랄 함량 분석}

넓미역의 미네랄은 $\mathrm{Ca}$ 가 $1589.1 \mathrm{mg}(100 \mathrm{~g}$ dry weight basis)으로 가장 많이 함유되어 있었으며, $\mathrm{Na}$ 와 $\mathrm{Mg}$ 가 각 각 $344.6,74.3 \mathrm{mg}$ 의 함유량으로 주요 미네랄로 밝혀졌고, $\mathrm{Fe}(1.5 \mathrm{mg}), \mathrm{Zn}(10.2 \mathrm{mg})$ 등은 미량으로 함유되어 있었다 (Table 3). 한편, 기장, 진도, 완도산 미역의 주요 미네랄은 $\mathrm{Ca}$ 가 76.3-101.2 mg으로 넓미역 보다 낮게 함유되어 있었 으며, $\mathrm{Na}$ 와 $\mathrm{Mg}$ 는 각각 393.8-525.1, 83.1-94.9 mg으로 넓 미역과 유사한 함유량을 보였다(Choi et al. 2008). 한편, $\mathrm{Im}$ et al. (2006)은 기장과 완도 다시마의 미네랄 함량을 연구 하였는데, 기장과 완도 다시마는 $\mathrm{Ca} 2,800 \mathrm{mg}, \mathrm{Na}$ $967.8 \mathrm{mg}, \mathrm{Mg} 486.8 \mathrm{mg}$ 으로 넓미역보다 높은 미네랄 함 유량을 보였다. 또한, Park et al. (2012) 등이 보고한 구멍 쇠미역의 주요 미네랄 $(\mathrm{Ca}: 2838.4 \mathrm{mg}$, Na: $967.8 \mathrm{mg}$, $\mathrm{Mg}: 486.8 \mathrm{mg}$ ) 역시 넓미역보다 높은 함유량을 보였다. 따라서, 넓미역은 다시마, 구멍쇠미역보다는 낮은 미네랄 함량을 나타내었지만, 기장, 진도, 완도산 미역과 비교 하 였을 때, $\mathrm{Ca}$ 는 더 많이 함유되고 있으며, $\mathrm{Na}$ 와 $\mathrm{Mg}$ 는 유

Table 3. Mineral contents of $U$. peterseniana

\begin{tabular}{cc}
\hline Minerals & $\begin{array}{c}\text { Contents } \\
\text { (mg/100 g of dry weight) }\end{array}$ \\
\hline $\mathrm{Na}$ & $344.6 \pm 1.9$ \\
$\mathrm{Mg}$ & $74.3 \pm 0.1$ \\
$\mathrm{Ca}$ & $1589.1 \pm 13.9$ \\
$\mathrm{Fe}$ & $1.5 \pm 0.1$ \\
$\mathrm{Zn}$ & $10.2 \pm 0.1$ \\
\hline
\end{tabular}


Table 4. Yields and total phenolic contents of EtOH extracts and hot-water extracts from $U$. peterseniana

\begin{tabular}{lcc}
\hline & EtOH extracts Hot water extracts \\
\hline Yield (\%) & $2.7 \pm 0.1$ & $17.7 \pm 1.2$ \\
Total phenolic contents & $15.7 \pm 1.4$ & $4.3 \pm 0.3$ \\
(mg GAE/g sample) & & \\
\hline
\end{tabular}

사하게 함유되어 있기 때문에 식품 영양학적으로 일반미 역보다 더 높은 가치를 가질 것으로 기대된다.

넓미역 EtOH 및 열수 추출물의 수율 및 총폴리페놀 함량 넓미역 $\mathrm{EtOH}$ 및 열수 추출물의 수율과 총폴리페놀 함 량은 Table 4에 보여준다. 넓미역 $\mathrm{EtOH}$ 추출물의 수율은 $2.7 \%$ 로 나타났는데, 이는 Cho et al. (2012)이 보고한 홍 조류 Symphyocladia latiuscula, Chondrus ocellatus, Carpopeltis affinis의 EtOH 추출물 수율 1.4-1.8\%와 유사 하였다. 하지만, 갈조류 Sargassum pallidum의 $70 \%$ $\mathrm{EtOH}$ 추출물 $12.7 \%$ (Ye et al. 2009), 구멍쇠미역의 $80 \%$ $\mathrm{EtOH}$ 추출물 $12.3 \%$ (Park et al. 2012)보다는 낮은 수율을 보였다. 한편 넓미역 열수 추출물의 수율은 $\mathrm{EtOH}$ 추출물 보다 높은 $17.7 \%$ 로, 갈조류 톳의 열수 추출물 $(16.2 \%)$ 과 유사한 값을 보였다(Kim et al. 1998).

해조류에 함유되어 있는 총폴리페놀 함량은 항산화 활 성과 높은 연관성을 갖는다(Duan et al. 2006). 따라서, 본 연구에서는 넓미역의 항산화 활성을 분석하기 위하여 넓 미역 추출물의 총폴리페놀 함량을 조사하였다. 그 결과, 넓미역 추출물의 총폴리페놀 함량은 $\mathrm{EtOH}$ 추출물이 $15.7 \mathrm{mg}(\mathrm{GAE} / \mathrm{g}$ sample)의 값을 보이면서 열수 추출물 $(4.3 \mathrm{mg})$ 보다 높게 나타났다. 넓미역 $\mathrm{EtOH}$ 추출물의 총 폴리페놀 함량은 구멍쇠미역의 $80 \% \mathrm{EtOH}$ 추출물 $(34.1 \mathrm{mg})$ 보다는 낮은 값을 보였지만(Park et al. 2012), 홍조류 $\mathrm{EtOH}$ 추출물의 총폴리페놀 함량(13.1-15.0 mg)과는 유사 한 값을 보였다(Cho et al. 2012). 이상의 결과에서 보듯이 해조류의 종 및 추출방법에 따라 다른 수율과 총폴리페놀 함량을 보이는 이유는 해조류는 채집시기, 서식 환경, 종 및 추출 방법에 따라 다른 생리활성을 갖는 대사산물들을 함유하고 있기 때문이다(Cho et al. 2010; Park et al. 2012).

\section{넓미역 EtOH 및 열수 추출물의 항산화 활성}

\section{$\mathrm{DPPH}$ 라디칼 소거능}

넓미역 $\mathrm{EtOH}$ 및 열수 추출물의 $\mathrm{DPPH}$ 라디칼 소거능 은 Fig. 1과 같다. 넓미역 $\mathrm{EtOH}$ 및 열수 추출물은 농도가 $62.5 \mu \mathrm{g} / \mathrm{mL}$ 에서 $1000 \mu \mathrm{g} / \mathrm{mL}$ 로 증가할수록 $\mathrm{DPPH}$ 라디 칼 소거능도 증가하였다. 특히, 넓미역 $\mathrm{EtOH}$ 추출물의 $1000 \mu \mathrm{g} / \mathrm{mL}$ 농도에서는 약 $70 \%$ 의 높은 $\mathrm{DPPH}$ 라디칼 소 거능을 보였으며, $500 \mu \mathrm{g} / \mathrm{mL}$ 농도에서는 $47 \%$ 로 약간 낮

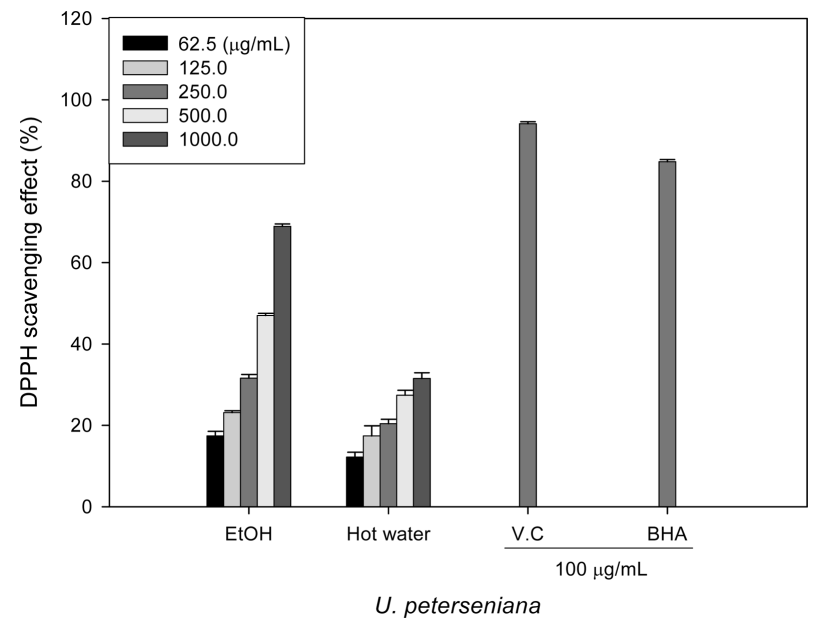

Fig. 1. DPPH (1,1-Diphenyl-1-picrylhydrazyl) radical scavenging activity of EtOH extracts and hot water extracts from $U$. peterseniana. Ascorbic acid (V.C) and butylated hydroxy anisole (BHA), each at a concentration of $100 \mu \mathrm{g} / \mathrm{mL}$, were used as positive controls

은 DPPH 라디칼 소거능을 보였다. 그러나, 넓미역 열수 추출물은 가장 높은 농도인 $1000 \mu \mathrm{g} / \mathrm{mL}$ 농도에서 약 $30 \%$ 의 낮은 $\mathrm{DPPH}$ 라디칼 소거능을 보였다. 비교 대조군 으로 사용한 V.C와 $\mathrm{BHA}$ 의 $\mathrm{DPPH}$ 라디칼 소거능은 $100 \mu \mathrm{g} / \mathrm{mL}$ 농도에서 각각 94.1, 84.8\%로 넓미역 $\mathrm{EtOH}$ 추출물 및 열수 추출물보다 높은 값을 보였다. 한편, Park et al. (2012)이 보고한 구멍쇠미역의 $80 \% \mathrm{EtOH}$ 추출물은 $1000 \mu \mathrm{g} / \mathrm{mL}$ 농도에서 $56.8 \%$ 의 $\mathrm{DPPH}$ 라디칼 소거능을 보였으며, 갈조류 S. pallidum의 $70 \% \mathrm{EtOH}$ 추출물은 $2000 \mu \mathrm{g} / \mathrm{mL}$ 농도에서도 넓미역보다 낮은 $30.5 \%$ 의 $\mathrm{DPPH}$ 라디칼 소거능을 보였다(Ye et al. 2009). 또한, Cho et al. (2012)이 보고한 S. latiuscula, C. ocellatus, C. affinis EtOH 추출물은 $1000 \mu \mathrm{g} / \mathrm{mL}$ 에서 $20 \%$ 이하의 낮은 $\mathrm{DPPH}$ 라디 칼 소거능을 보였으며, 녹조류 Chaetomorpha moniligera 와 Ulva pertusa $\mathrm{EtOH}$ 추출물의 $\mathrm{DPPH}$ 라디칼 소거능은 각각 $35.5 \%, 28.5 \%$ 로 넓미역의 $\mathrm{DPPH}$ 라디칼 소거능보 다 낮게 나타났다(Cho et al. 2010). 이상의 결과는 넓미역 의 $\mathrm{EtOH}$ 추출물은 효과적인 $\mathrm{DPPH}$ 라디칼 소거제로 사 용될 수 있을 것이라 예상된다.

\section{$A B T S$ 라디칼 소거능}

$\mathrm{ABTS}$ 라디칼 소거능은 지용성 및 수용성 성질의 항산 화 물질 모두 사용 가능한 보편적인 항산화 활성 측정 방 법으로, $\mathrm{ABTS}$ 의 양이온 라디칼의 흡광도가 항산화 활성 물질에 의해 감소되는 원리에 기초한 방법이다(Kim et al. 2002). 넓미역 $\mathrm{EtOH}$ 추출물의 ABTS 라디칼 소거능은 16.4-84.7\%, 열수 추출물의 ABTS 라디칼 소거능은 3.3- 


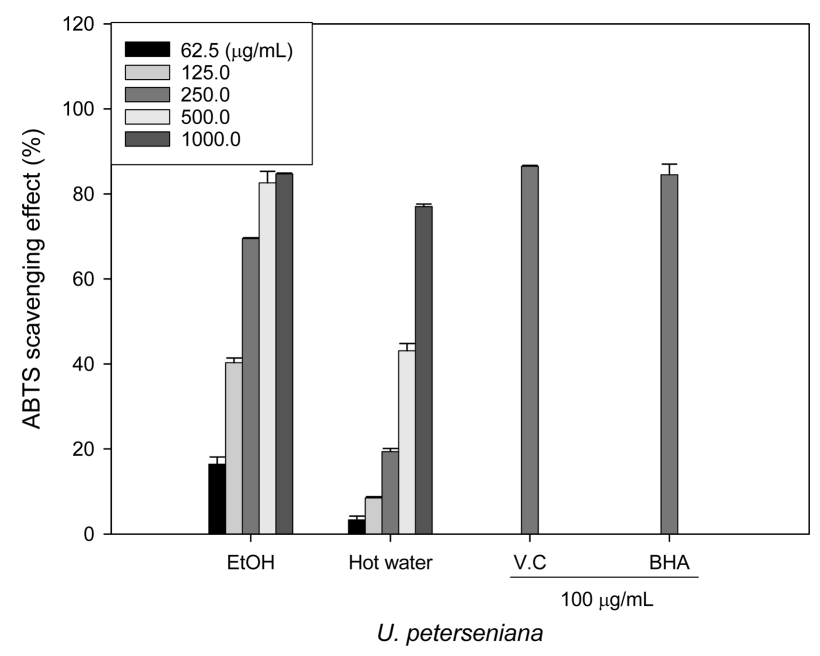

Fig. 2. ABTS (2,2'-azino-bis(3-ethylbenzothiazoline-6sulphonic acid)) radical scavenging activity of EtOH extracts and hot water extracts from $U$. peterseniana. Ascorbic acid (V.C) and butylated hydroxy anisole (BHA), each at a concentration of $100 \mu \mathrm{g} / \mathrm{mL}$, were used as positive controls

$77.0 \%$ 로 농도가 증가하면서 라디칼 소거능도 증가하였다 (Fig. 2). 특히 넓미역 $\mathrm{EtOH}$ 추출물의 ABTS 라디칼 소거 능은 $500 \mu \mathrm{g} / \mathrm{mL}$ 농도에서도 $82.6 \%$ 의 값을 보이면서 비 교 대조군으로 사용한 V.C (86.5\%) 및 $\mathrm{BHA}(84.5 \%)$ 의 $\mathrm{ABTS}$ 라디칼 소거능과 유사한 값을 보였으며, $250 \mu \mathrm{g} /$ $\mathrm{mL}$ 에서 역시 $69.5 \%$ 의 높은 $\mathrm{ABTS}$ 라디칼 소거능을 보 였다. 한편, 넓미역 열수 추출물의 ABTS 라디칼 소거능 은 $1000 \mu \mathrm{g} / \mathrm{mL}$ 농도에서는 $77.0 \%$ 로 높게 나타났으나, $500 \mu \mathrm{g} / \mathrm{mL}$ 농도에서는 $43.1 \%$ 로 약간 낮아졌다. 넓미역 $\mathrm{EtOH}$ 추출물의 ABTS 라디칼 소거능은 Ahn et al. (2011) 에 의해 보고된 Ishige okamurai 및 Undaria pinnatifida $\mathrm{EtOH}$ 추출물 $500 \mu \mathrm{g} / \mathrm{mL}$ 농도에서의 $\mathrm{ABTS}$ 라디칼 소거 능 $(45.0,20.1 \%)$ 보다 높게 나타났다. 하지만, Ecklonia cava, E. stolonifera, Eisenia bicyclis $\mathrm{EtOH}$ 추출물 $500 \mu \mathrm{g} / \mathrm{mL}$ 의 ABTS 라디칼 소거능(90.6, 91.2, 91.3\%) 보 다는 낮게 나타났다. 또한 넓미역 $\mathrm{EtOH}$ 및 열수 추출물의 ABTS 라디칼 소거능은 홍조류 $\mathrm{EtOH}$ 추출물 $(1000 \mu \mathrm{g} /$ $\mathrm{mL}, 1.1-16.2 \%)$ 보다 높은 $\mathrm{ABTS}$ 라디칼 소거능을 보였으 며, 넓미역 $\mathrm{EtOH}$ 추출물은 녹조류 $\mathrm{MeOH}$ 추출물 $(200 \mu \mathrm{g} /$ $\mathrm{mL}, 34.5 \%)$ 보다 높은 $\mathrm{ABTS}$ 라디칼 소거능을 보였다 (Shanab et al. 2011; Cho et al. 2012). 따라서, 넓미역 $\mathrm{EtOH}$ 및 열수 추출물은 효과적으로 $\mathrm{ABTS}$ 라디칼을 소거 하는 것으로 판단된다.

\section{환원력 측정(reducing power)}

환원력 측정은 ferric-ferricyanide $\left(\mathrm{Fe}^{3+}\right)$ 가 항산화 활성

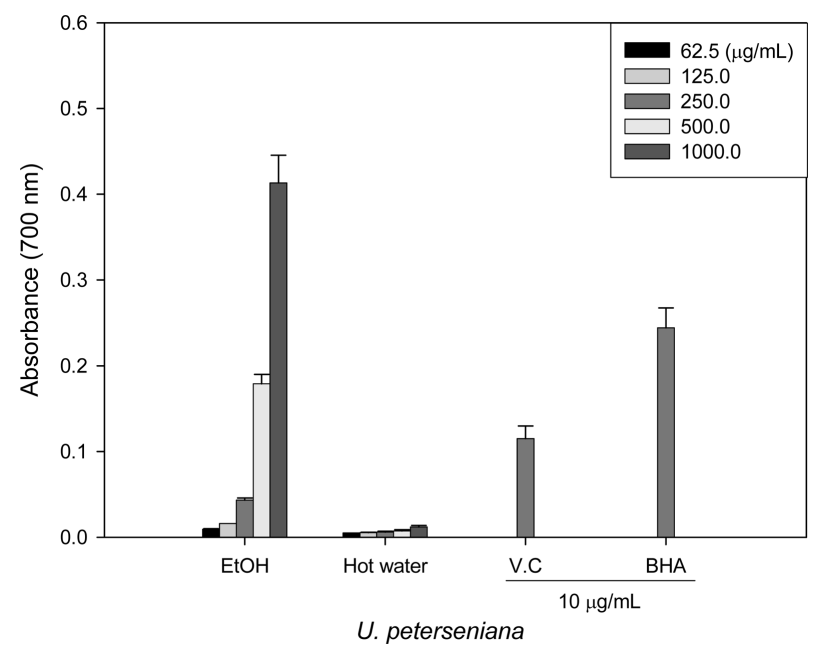

Fig. 3. Reducing power of EtOH extracts and hot water extracts from $U$. peterseniana. Ascorbic acid (V.C) and butylated hydroxy anisole (BHA), each at a concentration of $10 \mu \mathrm{g} / \mathrm{mL}$, were used as positive controls

물질에 의하여 ferrous $\left(\mathrm{Fe}^{2+}\right)$ 로 환원되는 능력을 $700 \mathrm{~nm}$ 에서 측정하는 방법으로, 넓미역 $\mathrm{EtOH}$ 및 열수 추출물의 reducing power는 Fig. 3에 나타내었다. 넓미역 EtOH 추 출물은 농도가 높아짐에 따라 reducing power가 증가 하 였으나, 넓미역 열수 추출물은 $1000 \mu \mathrm{g} / \mathrm{mL}$ 농도에서도 흡광도 0.012 로 reducing power를 거의 보이지 않았다. 또 한, 넓미역 $\mathrm{EtOH}$ 추출물은 $1000 \mu \mathrm{g} / \mathrm{mL}$ 농도에서 흡광도 0.413 의 값을 보이면서 비교 대조군으로 사용한 V.C $(0.115)$ 와 $\mathrm{BHA}(0.230)$ 보다 높은 reducing power를 보였다. 넓미 역 $\mathrm{EtOH}$ 추출물의 reducing power는 구멍쇠미역 $80 \%$ $\mathrm{EtOH}$ 추출물 $(1000 \mu \mathrm{g} / \mathrm{mL}, 0.25)$, U. pinnatifida의 $\mathrm{EtOH}$ 추출물 $(500 \mu \mathrm{g} / \mathrm{mL}, 0.123)$ 보다 높게 나타났으나, E. cava, E. stolonifera, E. bicyclis EtOH 추출물 $(500 \mu \mathrm{g} / \mathrm{mL}, 0.880$, $1.081,1.147)$ 보다는 낮았다(Ahn et al. 2011; Park et al. 2012). 한편, 넓미역 $\mathrm{EtOH}$ 추출물은 녹조류 E. prolifera의 $\mathrm{EtOH}$ 추출물 $(1000 \mu \mathrm{g} / \mathrm{mL}, 0.249)$, 홍조류 Porphyra yezoensis, Kappaphycus alvarezii의 $\mathrm{EtOH}$ 추출물(500 $\mu \mathrm{g} / \mathrm{mL}, 0.114,0.101)$ 보다 높은 reducing power를 보였다 (Ahn et al. 2011; Cho et al. 2011). 따라서, 넓미역 $\mathrm{EtOH}$ 추출물은 $\mathrm{Fe}^{3+}$ 를 $\mathrm{Fe}^{2+}$ 로 효과적으로 환원시킨다고 생각된다.

이상의 연구 결과에서 보듯이 넓미역 $\mathrm{EtOH}$ 추출물은 넓미역 열수 추출물 보다 높은 DPPH 및 $\mathrm{ABTS}$ 라디칼 소거능과 환원력을 보였다. 이러한 이유는 넓미역 $\mathrm{EtOH}$ 추출물에 함유되어 있는 phenolic compounds(fucoxanthin 등) 때문이라 예상되지만, 정확한 항산화 활성 성분을 분 석하기 위해서는 $\mathrm{HPLC}$ 를 이용하여 단일물질로의 분리가 
필요할 것으로 보인다.

\section{4. 결 론}

본 연구는 넓미역을 기능성 소재로 이용하기 위하여, 넓미역의 일반성분 분석, 알긴산 함량, 유리 아미노산 함 량, 미네랄 함량, 넓미역 $\mathrm{EtOH}$ 추출물 및 열수 추출물의 총폴리페놀 함량과 항산화 활성을 연구하였다. 그 결과, 넓미역은 수분 $12.5 \%$, 회분 $23.1 \%$, 조단백질 $9.7 \%$, 조지 방 $0.2 \%$ 및 총탄수화물 $54.5 \%$ 의 함량을 보였으며, 알긴 산이 $12.3 \%$ 함유되어 있었다. 넓미역의 주요 아미노산 함 량은 alanine이 가장 높았으며, phenylalanine, aminoethanol, valine, glutamic acid, phosphoserine 순으로 나타났다. 또 한 넓미역의 미네랄 함량은 $\mathrm{Ca}(1589.1 \mathrm{mg}), \mathrm{Na}(344.6$ $\mathrm{mg}), \mathrm{Mg}(74.3 \mathrm{mg})$ 가 $\mathrm{Fe}(1.5 \mathrm{mg}), \mathrm{Zn}(10.2 \mathrm{mg})$ 보다 높았 다. 넓미역 $\mathrm{EtOH}$ 및 열수 추출물의 총폴리페놀 함량은 각 각 $15.7 \mathrm{mg}$ 과 $4.3 \mathrm{mg}$ 으로 분석 되었으며, 넓미역 $\mathrm{EtOH}$ 추출물은 효과적인 $\mathrm{DPPH}, \mathrm{ABTS}$ 라디칼 소거능 및 reducing power를 보였고, 넓미역 열수 추출물은 높은 $\mathrm{ABTS}$ 라디칼 소거능을 나타내었다. 결론적으로 넓미역은 유리 아미노산 및 미네랄을 풍부하게 함유하고 있어 영양 학적 가치가 높으며, 넓미역 추출물은 높은 항산화 활성을 갖기 때문에 향후 기능성 식품, 화장품 및 의약품 소재로 사용될 가능성이 있을 것이라 기대된다.

\section{사 사}

이 연구는 한국해양과학기술원(Korea Institute of Ocean Science and Technology, KIOST)의 연구비(과제 번호: PE98921) 지원으로 수행되었으며, 이에 깊은 감사를 표합 니다.

\section{참고문헌}

AOAC (1984) Official Methods of Analysis, $14^{\text {th }}$ ed, Association of Official Analytical Chemists, Association of Official Agricultural Chemist International, Washington, DC, USA

AOAC (1995) Official Methods of Analysis, $16^{\text {th }}$ ed, Association of Official Analytical Chemists, Association of Official Agricultural Chemist International, Washington, DC, USA, $1298 \mathrm{p}$

Ahn SM, Hong YK, Kwon GS, Shon HY (2011) Evaluation of antioxidant and nitrite scavenging activity of seaweed extracts. J Life Sci 21:576-583

Azuma K, Nakayama M, Koshika M, Lpoushi K, Yamaguchi
Y, Kohata K, Yamaguchi Y, Ito H, Higashio H (1999) Phenolic antioxidants from the leaves of Corchorus olitorius L. J Agric Food Chem 47:3963-3966

Brand-Williams W, Cuvelier ME, Berset C (1995) Use of a free radical method to evaluate antioxidant activity. LWTFood Sci Technol 28:25-30

Cho ML, Lee DJ, You SG (2012) Radical scavenging activity of ethanol extracts and solvent partitioned fractions from various red seaweeds. Ocean and Polar Res 34:445-451

Cho ML, Lee HS, Kang IJ, Won MH, You SG (2011a) Antioxidant properties of extract and fractions from Enteromorpha prolifera, a type of green seaweed. Food Chem 127:999-1006

Cho ML, Lee BY, You SG (2011b) Relationship between oversulfation and conformation of low and high molecular weight fucoidans and evaluation of their in vitro anticancer activity. Molecules 16:291-297

Cho ML, Kang IJ, Won MH, Lee HS, You SG (2010) The antioxidant properties of ethanol extracts and their solventpartitioned fractions from various green seaweeds. J Med Food 13:1232-1239

Choi JS, Bae HJ, Kim YC, Park NH, Kim TB, Choi YJ, Choi EY, Park SM, Choi IS (2008) Nutritional composition and biological activities of the methanol extracts of sea mustard (Undaria pinnatifida) in Market. J Life Sci 18: 387-394

Duan XJ, Zhang WW, Li XL, Wang BG (2006) Evaluation of antioxidant property of extract and fractions obtained from red alga, Polysiphonia urceolata. Food Chem 95:37-43

Feskanich D, Ziegler RG, Michaud DS, Giovannucci EL, Speizer FE, Willett WC, Colditz GA (1992) Prospective study of fruit and vegetable consumption and risk of lung cancer among men and women. J Natl Cancer Inst 92:1812-1823

Hosokawa M, Wanezake S, Miyauchi K, Kurihara H, Kohno H, Kawabata J, Odashima S, Takahashi K (1999) Apoptosisinducing effect of fucoxanthin on human leukemia cell line HL-60. Food Sci Technol Res 5:243-246

Hwang EK, Gong YG, Ha DS, Park CS (2010a) Inducing the regeneration and maturation of free-living gametophytes of Ecklonia stolonifera Okamura (Laminariales, Phaeophyta). Korean J Fish Aquat Sci 43:231-238

Hwang EK, Gong YG, Park CS (2010b) Ecological characteristics of the endangered brown alga, Undariopsis peterseniana (Kjellman) Miyabe et okamura, at Jeju Island, Korea: Growth and maturation. Korean J Fish Aquat Sci 43:63-68

Hwang EK, Shim CH, Ha DS, Gong YG, Park CS (2011) 
Regeneration and maturation induction of free-living gametophytes of Undariopsis peterseniana for their mass production. Korean J Fish Aquat Sci 44:155-161

Im YG, Choi JS, Kim DS (2006) Mineral contents of edible seaweeds collected from Gijang and Wando in Korea. J Korean Fish Soc 36:16-22

Ito N, Hirose M, Fukushima S (1986) Modifying effects of antioxidants on chemical carcinogenesis. Toxicol Pathol 14:315-323

Kahkonen MP, Hopia AI, Vuorela HJ, Rauha JP, Pihlaja K, Kujala TS, Heinonen M (1999) Antioxidant activity of plant extracts containing phenolic compounds. J Agric Food Chem 47:3954-3962

Kang JW (1996) On the geographical distribution of marine algae in Korea. Bull Pusan Fish Coll 7:1-12

Khan MNA, Cho JY, Lee MC, Kang JY, Park NG, Fuji H, Hong YK (2007) Isolation of two anti-inflammatory and one pro-inflammatory polyunsaturated fatty acids from the brown seaweed Undaria pinnatifida. J Agric Food Chem 55:6984-6988

Kim DO, Lee KW, Lee HJ, Lee CY (2002) Vitamin C equivalent antioxidant capacity (VCEAC) of phenolic phytochemicals. J Agric Food Chem 50:3713-3717

Kim KY, Seo HD, Lee HS, Jo HY, Yang HC (1998) Studies on the blood anticoagulant polysaccharide isolated from hot water extracts of Hizikia fusiforme. J Korean Soc Food Sci Nutr 27:1204-1210

Lee IK, Choi DS, Oh YS, Kim GH, Lee JW, Kim KY, Yoo JS (1991) Marine algal flora and community structure of Chongsando Island on the south sea of Korea. Korean J Phycol 6:131-143

Lee KW, Koh SJ (1991) Algal flora of four islets without inhabitants along the coast of Cheju Island. Rep Sci Res, Four inhabited islets in the vicinity of Cheju Island. Cheju MBC 235-269

Lee YP (1998) Undariella, a new genus of the Alariaceae (Laminariales, Phaeophyta). Algae 13:419-426

Maeda H, Hosokawa M, Sashima T, Funayama K, Miyashita K (2005) Fucoxanthin from edible seaweed, Undaria pinnatifida, shows antiobesity effect through UCP1 expression in white adipose tissues. Biochem Biophys Res Commun 332:392-397

Nakayama R, Tamura Y, Kikuzaki H, Nakatani N (1999) Antioxidant effect of the constituents of Susabinori (Porphyra yezoensis). J Am Oil Chem Soc 76:649-653

Oyaizu M (1986) Studies on products of browning reaction prepared from glucoseamine. Jpn J Nutr 44:307-314
Park SJ, Min KJ, Park TG (2012) Nutritional characteristics and screening of biological activity of Agarum cribrosum. Korean J Food Nutr 25:842-849

Park KI, Donaghy L, Kang HS, Hong HK, Kim YO, Choi KS (2012) Assessment of immune parameters of manila clam Ruditapes philippinarum in different physiological conditions using flow cytometry. Ocean Sci J 47:19-26

Re R, Pellegrini N, Proteggente A, Pannala A, Yang M, Rice-Evans C (1999) Antioxidant activity applying an improved ABTS radical cation decolorization assay. Free Radic Biol Med 26:1231-1237

Regnstrom J, Nilsson J, Tornvall P, Landou C, Hamsten A (1992) Susceptibility to low-density lipoprotein oxidation and coronary atherosclerosis in man. Lancet 339:11831186

Rice-Evans CA, Miller HJ, Oaganga G (1996) Structure antioxidant activity relationships of flavonoids and phenolic acids. Free Radic Biol Med 20:933-956

Sachindra NM, Sato E, Haeda H, Hosokawa M, Niwano Y, Kohno M, Miyashita K (2007) Radical scavenging and singlet oxygen quenching activity of marine carotenoids fucoxanthin and its metabolites. J Agric Food Chem 55: 8516-8522

Safer AM, al-Nughamish AJ (1999) Hepatotoxicity induced by the antioxidant food additive, butylated hydroxytoluene (BHT), in rats: an electron microscopical study. Histol Histopathol 14:391-406

Shanab SMM, Shalaby EA, El-Fayoumy EA (2011) Enteromorpha compressa exhibits potent antioxidant activity. J Biomed Biotechnol 2011:726405. doi:10.1155/ 2011/726405

Yan XJ, Li XC, Zhou CX, Fan X (1996) Prevention of fish oil rancidity by phlorotannins from Sargassum kjellmanianum. J Appl Physiol 8:201-203

Ye H, Zhou C, Sun Y, Zhang X, Liu J, Hu Q, Zeng X (2009) Antioxidant activities in vitro of ethanol extract from brown seaweed Sargassum pallidum. Eur Food Res Technol 230:101-109

You BJ, Im YS, Jeong IH, Lee KH (1997) Effect extraction conditions on bile acids binding capacity in vitro of alginate extracted from sea tangle (Laminaria spp.). J Kor Fish Soc 30:31-38

Received Sep. 17, 2013

Revised Oct. 18, 2013

Accepted Nov. 15, 2013 